\title{
Molecular epidemiology of Vibrio nigripulchritudo, a pathogen of cultured penaeid shrimp (Litopenaeus stylirostris) in New Caledonia
}

\author{
Cyrille Goarant ${ }^{\underline{a},}$, , Yann Reynaud ${ }^{\underline{a}, \underline{b}}$, Dominique Ansquer ${ }^{\underline{a}}$, Sophie de Decker ${ }^{\underline{a}}$, Denis Saulnier ${ }^{\underline{b}}$ and \\ Frédérique le Roux
}

\author{
aIFREMER, Département Aquaculture en Nouvelle-Calédonie, BP 2059, 98846 Nouméa cedex, Nouvelle- \\ Calédonie \\ ${ }^{b}$ IFREMER, Laboratoire de Génétique et Pathologie BP 133, 17390 La Tremblade, France \\ Corresponding author : Cyrille.Goarant@ifremer.fr
}

\begin{abstract}
:
A collection of 57 isolates of Vibrio nigripulchritudo from either diseased or healthy shrimp and from shrimp farms environment was studied in order to gain a better understanding of the epidemiology of this pathogen, notably isolated from two distinct shrimp disease complexes. Molecular typing using two different techniques, arbitrarily primed PCR (AP-PCR) and multi-locus sequence typing (MLST), studied together with experimental pathology data allowed a relevant epidemiological insight into this possibly emerging pathogen. Additionally, results obtained with the two molecular typing techniques were congruent and allowed discriminating the strains associated with the "Summer Syndrome" from strains isolated from other contexts, especially the other shrimp vibriosis "Syndrome 93". These results highlight that the "Summer Syndrome" is most probably caused by an emergent clonal pathogen that therefore deserves surveillance and that AP-PCR can satisfactorily be used for that purpose
\end{abstract}

Keywords: Vibriosis; Mariculture; AP-PCR; MLST; Typing; Epidemiology; Virulence 


\section{INTRODUCTION}

Shrimp aquaculture has been constantly increasing over the last decades, providing now half of the world shrimp supplies [30]. However, this rapid increase in culture has often been impeded by very severe epizootics [19, 34]. Worldwide, viruses are major problems, being responsible for the most spectacular losses among shrimp [23, 33]. However, vibriosis is also an important disease among penaeid shrimp [3, 21, 22, 26, 36], but this has yet only received little research attention. Therefore, limited knowledge has been gained on these pathologies and little is known concerning the epidemiology of Vibrio spp that are pathogenic to farmed shrimp.

New Caledonia (a 450 x $50 \mathrm{~km}$ wide island in the South Pacific between $19^{\circ} \mathrm{S}$ and $23^{\circ} \mathrm{S}$ ), is a small producer regarding world global trade. However this industry has gained considerable economic importance in the last three decades, now representing the second major export sector of the country. Actually, the shrimp farming industry has major advantages, namely a tropical oceanic climate, a domesticated Litopenaeus stylirostris line reared in closed cycle for almost 25 years, an almost virus-free status, IHHNV (infectious hypodermal and hematopoietic necrosis virus) being the only known virus present and the domestic stock of $\underline{L}$. stylirostris being resistant to it [40]. Yet this industry is based on a unique domesticated but non-indigenous species, $\underline{L}$. stylirostris. So the emergence of an infectious disease would threaten its profitability and sustainability. In such a context, it is of prime importance to detect the emergence of pathogenic infectious agents as early as possible and to understand the mechanisms of infection in order to be able to control the disease. Actually, New Caledonian shrimp farming has been affected since 1993 by a cool season vibriosis causing high mortalities in juvenile shrimp reared in earthen ponds, that was shown to be caused by Vibrio penaeicida and was named Syndrome 93 [6, 12, 25, 31]. During Syndrome 93 epizootics, a few other Vibrio strains could be isolated from moribund shrimp septicemic hemocultures,

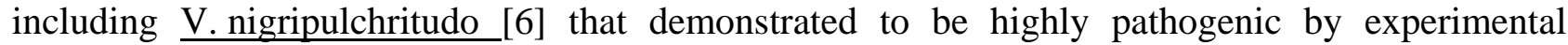
infection in healthy L. stylirostris [15]. These pathogenic strains were, at that time, geographically restricted to two adjoining farms within one bay [14] and therefore, zoosanitary recommendations were given in order to minimize the risk of disease spread. The industry's strategy has since been to avoid winter crops, thus limiting the impact of Syndrome 93. However $\underline{V}$. nigripulchritudo was yet isolated in late December 1997 from moribund shrimp obtained from two ponds at one farm located $50 \mathrm{~km}$ south of the original isolation. The organism was also causing an epizootic due to systemic vibriosis [11], but in high water temperature conditions that did not fit the classical Syndrome 93 epidemiology, which typically occurs at lower water temperatures $[13,25]$. This new disease, which was named "Summer Syndrome" has affected all summer crops on this farm ever since. Since 2002, it also affected a new farm built in the close proximity of the affected one. If it was to affect all shrimp farms, the profitability of the industry would be seriously threatened.

The facts that (i) $\mathrm{V}$. nigripulchritudo is associated with two distinct shrimp diseases and (ii) that one of these ("Summer Syndrome") is possibly an emergent disease highlight the need for accurate epidemiological data to gain appropriate knowledge and to propose adequate sanitary surveillance.

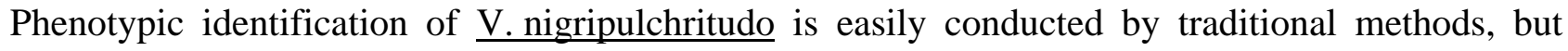
lacks a sufficient discriminating power for epidemiological studies. Therefore, the genetic structure of a New Caledonian $\underline{V}$. nigripulchritudo collection has been studied using two molecular typing methods over a selection of $58 \mathrm{~V}$. nigripulchritudo strains. The two methods used were Multi Locus Sequencing Typing, MLST, [24] and Arbitrarily Primed PCR, AP-PCR, [39]. Results were analysed together with virulence patterns of the strains that had been previously determined [15]. Here, we describe the results of this study, compare the two molecular typing techniques used, and propose a surveillance scheme of the potential emergence of this new pathogen for the shrimp aquaculture industry of New Caledonia. 


\section{MATERIALS AND METHODS}

\section{Bacterial strains and geographical data}

Both the type strain and wild-type isolates of Vibrio nigripulchritudo were used in this study. V. nigripulchritudo CIP $103192^{\mathrm{T}}$ (= ATCC 27043) was provided by Collection de l'Institut Pasteur. Fifty seven wild-type isolates, from both clinical and environmental origins, isolated between May 1995 and November 2003 in 13 different farms and 3 hatcheries along almost 300 kilometers of the New Caledonian West Coast were included in this study (Table 1). The origin, identification and virulence of these $\underline{\mathrm{V} \text {. nigripulchritudo }}$ isolates towards healthy $\underline{\mathrm{L} \text {. stylirostris }}$ were determined previously [6, 14, 15], (see table 1 ).

The shrimp farms and hatcheries included in the study are located on the southwest coast of New Caledonia (Fig. 1).

Clinical V. nigripulchritudo isolates originated from septicemic hemocultures associated with Syndrome 93 (= cool season vibriosis; 3 strains), Summer Syndrome (7 strains), and opportunistic vibriosis, i.e. affecting only a few shrimp under adverse pond conditions and lasting only a limited time (9 strains). Other strains were isolated when found (one or very few colonies) in hemocultures from either healthy shrimp (24 isolates) or moribund shrimp dying from a non bacterial cause (4 strains). Environmental isolates were isolated from pumping water in a Summer Syndrome affected farm (2 isolates), pond water or sediment pore water in the two Summer Syndrome affected farms (7 strains) and from a healthy crab (Portunus pelagicus) carapace swab (1 isolate). Identification to the species level was achieved on the basis of phenotyping tests and specific PCR confirmation as described elsewhere [15]. Additionally, V. penaeicida strain AM101 [6, 13, 14], isolated in a Syndrome 93 context was included in this study, as an outgroup for phylogenetic analysis.

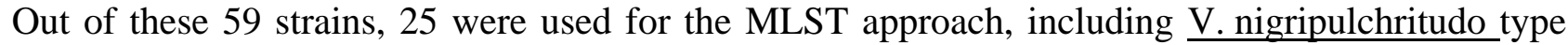
strain and $\underline{V}$. penaeicida AM101 as an outgroup (see Table 1). All of these 25 strains are deposited in the bacterial collection of the CRB (Centre de Ressources Biologiques, Laboratoire de Génétique et Pathologie, Institut Français de Recherche pour l'Exploitation de la MER [IFREMER], La Tremblade, France).

\section{Culture conditions and extraction of bacterial genomic DNAs}

Vibrio strains stored frozen at $-80^{\circ} \mathrm{C}$ in Marine Broth 2216E (Difco) with $17 \%$ glycerol were cultured in accordance with standard procedures [1] i.e. grown in Marine Broth 2216E (Difco) at $30^{\circ} \mathrm{C}$ with continuous shaking until the stationary phase of growth was reached, i.e. usually $18 \mathrm{~h}$. DNAs were extracted and purified as described elsewhere [18].

\section{AP-PCR}

Fingerprinting was performed as described previously [14]. Primers RSP and SP (see Table 2) were purchased from Proligo (Singapore). Fifty-microliter reaction mixtures were prepared with $100 \mathrm{ng}$ of DNA-1 X Taq polymerase buffer- $\mathrm{MgCl}_{2} 4 \mathrm{mM}-0.2 \mathrm{mM}$ each deoxynucleoside triphosphate (Sigma laboratories)-1.25 U of DNA polymerase (Qiagen). Amplification reactions were cycled twice in a 60-well Gene-Amp 9700 thermocycler (Applied BioSystems) through a low-stringency temperature profile and then 40 times through a high-stringency temperature profile as previously described [29]. Ten microliters of each reaction mixture was combined with $2 \mu \mathrm{l}$ loading buffer and loaded onto a $2 \%$ agarose gel with $1 \mathrm{X}$ TBE (90 mM Tris-borate, $2 \mathrm{mM}$ EDTA), and electrophoresis was performed at $40 \mathrm{~V}$ overnight. After ethidium bromide staining, the gel was then photographed under UV trans-illumination. In accordance with Welsh and McClelland [39], only major bands were considered in the analysis as share-derived characters, and this allowed the construction of a key for type grouping of the strains according to the amplicons produced with a given primer. Major bands were considered as present (1) or absent (0) in each fingerprint. All major bands for both primers were put together in a single analysis. The resulting matrix was analyzed using the PopGene 16 freeware [41] to build a dendrogram based on Nei’s genetic distances [27]. 


\section{Multi Locus Sequence Typing}

Six genes were considered for the MLST approach: $16 S \mathrm{rDNA}, \operatorname{gyr} B, r p o D, r c t B$, toxR and $\operatorname{rec} A$ $[20,37]$. Primers sequences and annealing temperatures according to gene are given in Table 2 . The amplicons with the expected size were purified using a Qiaex II Gel Extraction Kit (Qiagen). PCR product were then denatured for $2 \mathrm{~min}$ at $96^{\circ} \mathrm{C}$ and mixed (final volume $10 \mu \mathrm{l}$ ) with $0.4 \mu \mathrm{l} \mathrm{ABI}$ Prism Big Dye Terminator ready reaction mix (Applied Biosystems), forward or reverse primer $0.6 \mu \mathrm{M}$ and buffer 5x. Cycle sequencing reaction was performed using a Gene Amp PCR System 2700 (Applied Biosystem), following instruction of the manufacturer. Separation of the DNA fragments was carried out in an ABI PRISM 3100 Genetic Analyzer (Applied Biosystems).

Concatemers of sequences were aligned with BioEdit ${ }^{\circledR}$ [16], phylogenetic trees were built using Phylo-win program [9] applied to Neighbour Joining method and Kimura's 2-parameter distances [10]. Reliability of topologies was assessed by the bootstrap method with 1000 replicates.

\section{AP-PCR typing:}

\section{RESULTS}

Both primers permitted the amplification of all tested DNA's, giving complex profiles with up to 18 different bands for each strain, over a total of 28 and 26 different amplicon sizes for primers SP and

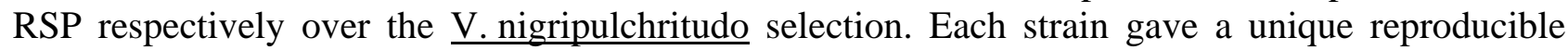
profile when using the correct amount of genomic DNA for the amplification using the same thermocycler. The complex fingerprint profiles permitted an intra-specific discrimination between V. nigripulchritudo strains (Fig. 2, as an example). When considering only major bands, each fingerprint was scored with 6 to 12 bands out of 16 for each primer. In order to characterize the outgroup (V. penaeicida strain AM101) 6 additional bands were necessary for primer SP and 8 for primer RSP. The analysis, thus relying on a matrix of presence/absence of 46 bands for 59 bacterial strains resulted in constructing a dendrogram, which is presented in figure 3.

$\mathrm{V}$. nigripulchritudo wild type isolates could be grouped into 4 major clusters $(A, B, C$ and $D$, see Fig. 3), out of which 2 clusters (A and B) grouped all virulent isolates. Though sub-clusters could be considered in these two clusters, they evidenced a low genetic diversity compared to clusters $C$ and $\mathrm{D}$ that contained only non-virulent isolates.

\section{Multi Locus Sequence Typing:}

A total of 3,430 bp corresponding to partial sequences of the 6 genes $r e c A, r p o D$, toxR, 16S rDNA, gyrB et $r c t B$ were aligned. This permitted the construction of a concatemer phylogenetic tree by Neighbour joining Method and Kimura's 2-parameter distances (Fig. 4). The concatemer resulted in at least $97 \%$ overall homology between nucleotidic sequences within the $24 \mathrm{~V}$. nigripulchritudo strains studied. The most polymorphic gene proved to be $g y r B$ with $95 \%$ gene sequence similarity, then $96 \%$ for recA, $97 \%$ for toxR, $98 \%$ for $r p o D$ and $r c t B$ and $99 \%$ for $16 \mathrm{~S}$ rDNA. Regarding genetic structuring of the sub-selection of strains, one cluster with very low genetic variability groups only strains being virulent to $\underline{L}$. stylirostris (cluster A'), another cluster, with higher genetic variability whatever gene being considered, groups virulent together with avirulent strains (cluster B'). Lastly, all other non-virulent strains belong to none of these two main clusters.

\section{Genospecies identification:}

The sequence similarities obtained in 16S rDNA being all above 99\% confirm that all of the 24 strains studied in MLST belong to the species $V$. nigripulchritudo, considering Stackebrandt and Embley [35] who advise a level of intraspecific similarity of $\geq 98 \%$ in 16 S rDNA gene sequences. Because at least one strain from each AP-PCR cluster was used for the MLST approach and therefore its 16S rDNA gene sequenced, it confirmed the belonging of these isolates to the species $V$. nigripulchritudo $[14,15]$. 


\section{DISCUSSION}

Both techniques permitted discriminations and groupings between isolates. MLST and AP-PCR are very powerful DNA typing tool, which have shown a high degree of intraspecies discriminatory power for bacterial pathogens [14, 28, 29, 38]. The overwhelming advantage of MLST is that sequence data are portable and cumulative between laboratories allowing to exchange data for multi-laboratory epidemiological studies. Nevertheless this technique is time consuming and expensive. AP-PCR is easier to develop, requires no prior knowledge of the sequences of the organism to be studied and is an easy and rapid technique. However, it has been shown to present a lack of reproducibility depending on laboratory equipments and practices $[2,4,5,8]$.

Interestingly, the clusters that were evidenced by either technique were consistent. This provides an inter-validation of the results, one technique being based on the sequence analysis of major household genes while the other technique relies on a global examination of the complete genome. Therefore, the epidemiological interpretation can be considered as relying on very solid genomic basis. Thus the AP-PCR, because being easily implemented and thanks to this "inter-validation" with MLST results, could be a reliable tool for molecular epidemiological studies of both shrimp diseases caused by V. nigripulchritudo in New Caledonia.

Actually, this study gives very informative insights into the epidemiology of $\underline{\mathrm{V} \text {. nigripulchritudo in }}$ New Caledonian shrimp culture. One cluster (B) groups all Syndrome 93 isolates, from one single geographical origin [14] together with strains from an opportunistic vibriosis outbreak that occurred in a farm from the same bay during the summer 2002-2003. This demonstrates that this cluster, though being originally involved in winter mortalities (Syndrome 93) can also possibly be involved in opportunistic outbreaks during summer months.

The major cluster (A) includes 20 wild type isolates and puts together all Summer Syndrome isolates from diseased animals, from both affected farms, whatever their date of isolation, over more than 3 years covering 4 culture cycles. Together with these strains, a few environmental isolates from the affected farms (sediment pore water or pond water) demonstrate that they may be environmentally-transmitted. This evidences that the Summer Syndrome is most probably attributable to a single pathogenic clone, surviving from one year to the next in the shrimp farm environment then re-developing inside the grow out system at the next crop. Also within this cluster, other isolates originate from opportunistic mortality outbreaks from other farms or hatcheries or from healthy juvenile shrimp from both Summer Syndrome-affected and non-affected farms all along the West coast of New Caledonia. This not only highlights the major role of environmental or zootechnical factors in the dynamics of the Summer Syndrome in the affected farms but also demonstrates that this pathogenic $\mathrm{V}$. nigripulchritudo cluster already has a wide geographical distribution. Therefore, it can be assumed that the emergence of Summer Syndrome does not correspond to the geographical extension of pathogenic $\underline{V}$. nigripulchritudo strains associated with Syndrome 93, but merely corresponds to the selection of another pathogenic clone within a shrimp farm environment.

The selection of bacterial strains used in this study was composed of a single strain conserved for each individual shrimp, this isolate being considered representative of clonal $\mathrm{V}$. nigripulchritudo being present in the shrimp hemolymph, except in one moribund shrimp (2 strains Wn13 and Wn14) and one healthy carrier shrimp (3 strains AgMn1, AgMn2 and AgMn3) [15]. So it was considered that one infected shrimp would carry $\underline{V}$. nigripulchritudo cells from a single clonal origin. However, it was demonstrated that other marine invertebrates, namely oysters, could carry non-clonal (both human-pathogenic and non-pathogenic) $\underline{V}$. parahaemolyticus cells at the same time [7]. Even though within the few strains originating from the same animals that we included in this study, there was no evidence of multi-clonal carriage of $\mathrm{V}$. nigripulchritudo in shrimp, further work could consider verifying our assumption, notably study if shrimp can carry both virulent and non-virulent strains at the same time. 
When comparing the molecular typing with experimental pathology results, it must be noted that some strains genetically close to the Syndrome 93 isolates (cluster B) demonstrated no experimental virulence towards L. stylirostris, whereas strains from the "Summer Syndrome" cluster (A) all demonstrated virulence. Still, even within this latter cluster, various levels of virulence could probably be evidenced [15] with more discriminative experimental infection models [32].

Still, V. nigripulchritudo from both Syndrome 93 and Summer Syndrome clusters could be isolated from opportunistic vibriosis episodes or even from apparently healthy shrimp in non-diseased farms. This demonstrates that the disease is the result of complex interactions between the pathogen, the shrimp (host) and their environment. As a response, IFREMER (the French Institute for Marine Sciences) has developed a specific research program, named DeSanS (possibly translated as Stylirostris Health Challenge), that is based on a multidisciplinary approach (rearing technology, pond ecosystem studies, shrimp eco-physiology and immunology, nutrition, pathology and genetics). It aims at gaining a global explanation scheme of both seasonal vibriosis as a contribution to strengthen the sustainability of New Caledonian aquaculture [17]. Summer syndrome being currently a research priority within DeSanS, a representative strain of this disease was chosen in order to study virulence determinants pathogenesis and host damages. Comparatively with a non-virulent isolate, these strains are being studied for their production of extracellular toxic products, infection capacity and shrimp response. Lastly, a genomic subtraction using Suppressive Subtractive Hybridization is currently in progress.

\section{Acknowledgments}

This work was partly supported by grants from the South and North Provinces of New Caledonia, Ifremer and the French Ministry of Research. Thanks are due to J. Herlin, A.-L. Marteau and B. Wapotro for participating to the isolation of some $\mathrm{V}$. nigripulchritudo strains from 1999 on and to the Territorial Laboratory of Veterinary Diagnosis of New Caledonia for maintaining and supplying the 1995 isolates. The authors are indebted to B. Austin for giving a critical advice and valuable corrections to the manuscript. 


\section{References:}

[1] B. Austin, M. Alsina, D.A. Austin, A.R. Blanch, F. Grimont, P.A.D. Grimont, J. Joffre, S. Koblavi, J.L. Larsen, K. Pedersen, T. Tiainen, L. Verdonck, J. Swings, Identification and typing of Vibrio anguillarum: a comparison of different methods. Syst. Appl. Microbiol. 18 (1995):285-302.

[2] P. Bidet, V. Lalande, B. Salauze, B. Burghoffer, V. Avesani, M. Delmée, A. Rossier, F. Barbut, J. C. Petit, Comparison of PCR-Ribotyping, Arbitrarily Primed PCR, and Pulsed-Field Gel Electrophoresis for Typing Clostridium difficile. J. Clin. Microbiol. 38 (2000):2484-2487.

[3] J.A. Brock, B LeaMaster, A look at the principal bacterial, fungal and parasitic diseases of farmed shrimp. In J. Wyban (Eds.), Proceedings of the Special Session on Shrimp Farming, World Aquaculture Society, Baton Rouge, LA, 1992, pp. 212-226.

[4] E. Chachaty, P. Saulnier, A. Martin, N. Mario, A. Andremont, Comparison of ribotyping, pulsed-field gel electrophoresis and random amplified polymorphic DNA for typing Clostridium difficile strains. FEMS Microbiol. Lett. 122 (1994):61-68.

[5] M.C. Collier, F. Stock, P.C. DeGirolami, M.H. Samore, C.P. Cartwright, Comparison of PCRbased approaches to molecular epidemiologic analysis of Clostridium difficile. J Clin Microbiol. 34 (1996):1153-1157.

[6] R. Costa, I. Mermoud, S. Koblavi, B. Morlet, P. Haffner, F. Berthe, M. Le Groumellec, P. Grimont, Isolation and characterization of bacteria associated with a Penaeus stylirostris disease (Syndrome 93) in New Caledonia. Aquaculture 164 (1998):297-309.

[7] A. DePaola, J.L. Nordstrom, J.C. Bowers, J.G. Wells, D.W. Cook, Seasonal abundance of total and pathogenic Vibrio parahaemolyticus in Alabama oysters. Appl. Environ. Microbiol. 69 (2003):1521-1526.

[8] D.L. Ellsworth, K.D. Rittenhouse, R.L. Honeycutt, Artifactual variation in randomly amplified polymorphic DNA banding patterns. BioTechniques. 14 (1993):214-217.

[9] N. Galtier, M. Gouy C. Gautier, Seaview and Phylo_win, two graphic tools for sequence alignment and molecular phylogeny. Comput. Appl. Biosci. 12 (1996):543-548.

[10] O. Gascuel, BIONJ: an improved version of the NJ algorithm based on a simple model of sequence data. Mol. Biol. Evol. 14 (1987):685-695.

[11] C. Goarant, J. Herlin, D. Ansquer, F. Imbert, D. Domalain, A.L. Marteau, Épidémiologie de Vibrio nigripulchritudo dans le cadre du Syndrome d'été : résultats préliminaires du programme DESANS. In : C. Goarant, A. Herbland, Y. Harache, C. Mugnier (Eds.), Styli 2003, Trente ans de crevetticulture en Nouvelle-Calédonie, Ifremer Éd., Actes Colloq., 38(2004): 210-215. (in french with english abstract).

[12] C. Goarant, J. Herlin, D. Ansquer, R. Brizard, AL. Marteau, Vibrio penaeicida and Syndrome 93 in New Caledonian prawn farming: review and perspectives. In : C. Goarant, A. Herbland, Y. Harache, C. Mugnier (Eds.), Styli 2003, Trente ans de crevetticulture en NouvelleCalédonie, Ifremer Éd., Actes Colloq., 38(2004): 203-209 (in french with english abstract).

[13] C. Goarant, J. Herlin, R. Brizard, A.L. Marteau, C. Martin, B. Martin, Toxic factors of Vibrio strains pathogenic to shrimp. Dis. Aquat. Org. 40 (2000): 101-107. 
[14] C. Goarant, F. Mérien, F. Berthe, I. Mermoud, P. Pérolat, Arbitrarily primed PCR to type Vibrio spp. pathogenic for shrimp. Appl. Environ. Microbiol. 65 (1999): 1145-1151.

[15] C. Goarant, D. Ansquer, J. Herlin, D. Domalain, F. Imbert, S. De Decker, "Summer Syndrome" in Litopenaeus stylirostris in New Caledonia: Pathology and epidemiology of the etiological agent, Vibrio nigripulchritudo. Aquaculture, in press, published online 24 August 2005.

[16] T.A. Hall, BioEdit: a user-friendly biological sequence alignment editor and analysis program for Windows 95/98/NT. Nucl. Acids Symp. Ser. 41 (1999): 95-98.

[17] Y. Harache, A. Herbland, Le programme DESANS (Défi Santé Stylirostris) : une démarche comparable au Défi MOREST appliquée à la filière crevette Calédonienne. In : C. Goarant, A. Herbland, Y. Harache, C. Mugnier (Eds.), Styli 2003, Trente ans de crevetticulture en Nouvelle-Calédonie, Ifremer Éd., Actes Colloq., 38(2004): 31-38. (in french with english abstract).

[18] D.P. Jackson, J.D. Hayden, P. Quirke, Extraction of nucleic acid from fresh and archival material. In: M.J. McPherson, P. Quirke, G.R. Taylor (Eds.) PCR: a practical approach. IRL Press at Oxford University Press, Oxford, 1991, pp 29-49.

[19] N. Kautsky, P. Ronnback, M. Tedengren, M. Troell, Ecosystem perspectives on management of disease in shrimp pond farming. Aquaculture 191 (2000):145-161.

[20] F. Le Roux, A. Goubet, F.L. Thompson, N. Faury, M. Gay, J. Swings, D. Saulnier, Vibrio gigantis sp. nov., isolated from the haemolymph of cultured oysters (Crassostrea gigas). Int. J. Syst. Evol. Micr., in press, published online 10 June 2005.

[21] D.V. Lightner, Vibrio disease of penaeid shrimp. In : C.J. Sindermann, D.V. Lightner (Eds.), Disease diagnosis and control in North American marine aquaculture. Elsevier, Amsterdam, 1998, pp. 42-47.

[22] D.V. Lightner, D.H. Lewis, A septicemic bacterial disease syndrome of penaeid shrimp. Mar. Fish. Rev. 37 (1975): 25-28.

[23] D.V. Lightner, R.M. Redman, Shrimp diseases and current diagnostic methods. Aquaculture 164 (1998): 201-220.

[24] M.C. Maiden, J.A. Bygraves, E. Feil , G. Morelli, J.E. Russell, R. Urwin, Q. Zhang, J. Zhou, K. Zurth, D.A., Caugant, I.M. Feavers, M. Achtman B.G., Spratt, Multilocus sequence typing: A portable approach to the identification of clones within populations of pathogenic microorganisms. Proc. Natl. Acad. Sci. U S A. 95 (1998): 3140-3145.

[25] I. Mermoud, R. Costa, O. Ferré, C. Goarant, P. Haffner, Syndrome 93 in New Caledonian outdoor rearing ponds of Penaeus stylirostris: history and description of the three major outbreaks. Aquaculture 164 (1998): 323-335.

[26] L.L. Mohney, D.V. Lightner, An epizootic of vibriosis in Ecuadorian pond-reared Penaeus vannamei Boone (Crustacea: Decapoda). J. World Aquacult. Soc. 25 (1994): 116-125.

[27] M. Nei, Estimation of average heterozygosity and genetic distance from a small number of individuals. Genetics 89 (1978): 583-590. 
[28] Y.A. O'Shea, F.J. Reen, A.M. Quirke, E.F. Boyd, Evolutionary genetic analysis of the emergence of epidemic Vibrio cholerae isolates on the basis of comparative nucleotide sequence analysis and multilocus virulence gene profiles. J. Clin. Microbiol. 42 (2004): 46574671.

[29] P. Perolat, F. Merien, W.A. Ellis, G. Baranton, Characterization of Leptospira isolates from serovar hardjo by ribotyping, arbitrarily primed PCR, and mapped restriction site polymorphisms. J. Clin. Microbiol. 32 (1994): 1949-1957.

[30] B. Rosenberry, World shrimp farming 2004. Shrimp News International, San Diego, CA, 2004.

[31] D. Saulnier, J.C. Avarre, G. Le Moullac, D. Ansquer, P. Levy, V. Vonau, Rapid and sensitive PCR detection of Vibrio penaeicida, the putative etiological agent of Syndrome 93 in New Caledonia. Dis. Aquat. Org. 40 (2000): 109-115.

[32] D. Saulnier, P. Haffner, C. Goarant, P. Levy, D. Ansquer, Experimental infection models for shrimp vibriosis studies : a review. Aquaculture 191 (2000): 133-144.

[33] A.M. Schuur, Evaluation of biosecurity applications for intensive shrimp farming. Aquacult. Eng. 28 (2003): 3-20.

[34] V.J. Smith, J.H. Brown, C. Hauton, Immunostimulation in crustaceans: does it really protect against infection? Fish Shellfish Immun. 15 (2003): 71-90.

[35] E. Stackebrandt, T.M. Embley, Diversity of uncultured microorganisms in the environment, In: R. R. Cowell, D. J. Grimes (Eds.), Nonculturable microorganisms in the environments, ASM, Washington DC, 2000, pp. 55-57.

[36] Y. Takahashi, Y. Shimomaya, K. Momomaya, Pathogenicity and characteristics of Vibrio sp. isolated from cultured kuruma prawns Penaeus japonicus Bate. Bull. Jpn. Soc. Sci. Fish. 51 (1985): 721-730.

[37] C.C. Thompson, F.L. Thompson, K. Vandemeulebroecke, B. Hoste, P. Dawyndt, J. Swings, Use of recA as alternative phylogenetic marker in the family Vibrionaceae. Int. J. Syst. Evol. Micr. 54 (2004): 919-924.

[38] M.C.L. Vickery, A.L. Smith, A. DePaola, D.D. Jones, R.J. Steffan, A.K. Bej, Optimization of the arbitrarily-primed polymerase chain reaction (AP-PCR) for intra-species differentiation of Vibrio vulnificus. J. Microbiol. Meth. 33 (1998): 181-189.

[39] J. Welsh, M. McClelland, Fingerprinting genomes using PCR with arbitrary primers. Nucleic Acids Res. 18 (1990): 7213-7218.

[40] M. Weppe, J.R. Bonami, D.V. Lightner, AQUACOP, Demostración de la altas cualidades de la cepa de P. stylirostris (AQUACOP SPR 43) resistente al virus IHHN. In Escuela Superior Politécnica del Litoral (Eds.) Memorias I Congreso Ecuatoriano de acuicultura, Guayaquil, 1993, pp. 229-232. (in spanish).

[41] F.C. Yeh, T.J.B. Boyle, Population genetic analysis of co-dominant and dominant markers and quantitative traits. Belg. J. Bot. 129 (1997): 157. 
Table 1: Vibrio nigripulchritudo type strain and field isolates used in this study

Bold: Isolates from farms which are affected by the Summer Syndrome.

Italics: Isolates collected during surveys specifically dedicated to the isolation of $\underline{\text { V. nigripulchritudo strains. }}$

Virulence as determined in text: $\mathrm{V}$ stands for virulent and $\mathrm{N}$ for Non-virulent.

The names of wild type isolates refer to the initials of the grow out farms and hatcheries as mentioned on the map in Fig. 1.

* Virulence data from Goarant et al. [15]

\begin{tabular}{|c|c|c|c|c|c|}
\hline Strain name & $\begin{array}{l}\text { Date of } \\
\text { isolation }\end{array}$ & context & $\begin{array}{l}\text { Virulence to } L \text {. } \\
\text { stylirostris * }\end{array}$ & MLST & Reference \\
\hline CIP $103195^{\top}$ & \multicolumn{2}{|c|}{ V. nigripulchritudo type strain } & $\mathrm{N}$ & $X$ & \\
\hline AM102 & May 1995 & $\begin{array}{c}\text { S93, moribund shrimp } \\
\text { hemoculture }\end{array}$ & V & $x$ & {$[6 ; 14]$} \\
\hline AM 115 & May 1995 & $\begin{array}{l}\text { S93, moribund shrimp } \\
\text { hemoculture }\end{array}$ & V & $\mathrm{x}$ & {$[6 ; 14]$} \\
\hline SO65 & May 1995 & $\begin{array}{c}\text { S93, moribund shrimp } \\
\text { hemoculture }\end{array}$ & V & $x$ & {$[6 ; 14]$} \\
\hline SFn1 & March 2000 & $\begin{array}{l}\text { Summer syndrome, moribund } \\
\text { shrimp hemoculture }\end{array}$ & V & $\mathrm{x}$ & [15] \\
\hline SFn2 & March 2000 & $\begin{array}{l}\text { Summer syndrome, moribund } \\
\text { shrimp hemoculture }\end{array}$ & V & & [15] \\
\hline SFn27 & $\begin{array}{l}\text { December } \\
2000\end{array}$ & $\begin{array}{c}\text { Sediment pore water, diseased } \\
\text { pond }\end{array}$ & V & $\mathrm{x}$ & [15] \\
\hline SFn48 & $\begin{array}{l}\text { November } \\
2001\end{array}$ & $\begin{array}{c}\text { Summer syndrome, moribund } \\
\text { shrimp hemoculture }\end{array}$ & V & & [15] \\
\hline SFn49 & $\begin{array}{c}\text { November } \\
2001\end{array}$ & $\begin{array}{c}\text { Growout pond water, diseased } \\
\text { pond }\end{array}$ & V & & [15] \\
\hline SFn105 & $\begin{array}{c}\text { February } \\
2002 \\
\end{array}$ & $\begin{array}{c}\text { Growout pond water, diseased } \\
\text { pond }\end{array}$ & V & & [15] \\
\hline SFn106 & $\begin{array}{l}\text { February } \\
2002\end{array}$ & $\begin{array}{l}\text { Summer syndrome, moribund } \\
\text { shrimp hemoculture }\end{array}$ & V & & [15] \\
\hline SFn111 & March 2002 & $\begin{array}{c}\text { Carapace of a healthy crab } \\
\text { (Portunus pelagicus), diseased } \\
\text { farm }\end{array}$ & & & [15] \\
\hline SFn115 & March 2002 & $\begin{array}{l}\text { Lagoon water in front of pumps, } \\
\text { diseased farm }\end{array}$ & & $x$ & [15] \\
\hline SFn118 & April 2002 & $\begin{array}{l}\text { Lagoon water in front of pumps, } \\
\text { diseased farm }\end{array}$ & $N$ & $x$ & [15] \\
\hline SFn127 & $\begin{array}{l}\text { November } \\
2002 \\
\end{array}$ & $\begin{array}{c}\text { Healthy shrimp hemoculture, } \\
\text { before disease outbreak }\end{array}$ & V & & [15] \\
\hline SFn128 & $\begin{array}{l}\text { December } \\
2002 \\
\end{array}$ & $\begin{array}{c}\text { Summer syndrome, moribund } \\
\text { shrimp hemoculture }\end{array}$ & V & & [15] \\
\hline SFn135 & $\begin{array}{l}\text { December } \\
2002\end{array}$ & $\begin{array}{c}\text { Growout pond water, diseased } \\
\text { pond }\end{array}$ & V & $x$ & [15] \\
\hline AgMn1 & \multirow{3}{*}{$\begin{array}{l}\text { October } \\
2003\end{array}$} & \multirow{3}{*}{$\begin{array}{c}\text { Healthy shrimp hemoculture, } \\
\text { before disease outbreak (same } \\
\text { animal) }\end{array}$} & $\mathrm{N}$ & $x$ & [15] \\
\hline AgMn2 & & & $\mathrm{N}$ & & [15] \\
\hline AgMn3 & & & $\mathrm{N}$ & & [15] \\
\hline AgMn7 & $\begin{array}{l}\text { November } \\
2003\end{array}$ & $\begin{array}{c}\text { Healthy shrimp hemoculture, } \\
\text { before disease outbreak }\end{array}$ & V & & [15] \\
\hline AgMn8 & $\begin{array}{l}\text { November } \\
2003\end{array}$ & $\begin{array}{l}\text { Summer syndrome, moribund } \\
\text { shrimp hemoculture }\end{array}$ & V & & [15] \\
\hline AgMn9 & $\begin{array}{l}\text { November } \\
2003\end{array}$ & $\begin{array}{c}\text { Growout pond water, diseased } \\
\text { pond }\end{array}$ & V & & [15] \\
\hline AgMn10 & $\begin{array}{l}\text { November } \\
2003\end{array}$ & $\begin{array}{l}\text { Summer syndrome, moribund } \\
\text { shrimp hemoculture }\end{array}$ & V & & [15] \\
\hline AgMn12 & $\begin{array}{l}\text { November } \\
2003\end{array}$ & $\begin{array}{c}\text { Sediment pore water, diseased } \\
\text { pond }\end{array}$ & V & & [15] \\
\hline
\end{tabular}




\begin{tabular}{|c|c|c|c|c|c|}
\hline AgMn13 & $\begin{array}{l}\text { November } \\
2003\end{array}$ & $\begin{array}{c}\text { Sediment pore water, diseased } \\
\text { pond }\end{array}$ & V & & [15] \\
\hline POn2 & April 2002 & $\begin{array}{l}\text { Healthy shrimp hemoculture, } \\
\text { healthy pond } 2 \text {, healthy farm }\end{array}$ & $\mathrm{V}$ & & [15] \\
\hline POn3 & April 2002 & $\begin{array}{c}\text { Healthy shrimp hemoculture, } \\
\text { healthy pond } 3 \text {, same healthy } \\
\text { farm }\end{array}$ & V & $x$ & [15] \\
\hline POn4 & April 2002 & $\begin{array}{l}\text { Healthy shrimp hemoculture, } \\
\text { healthy pond } 6 \text {, same healthy } \\
\text { farm }\end{array}$ & $\mathrm{N}$ & $x$ & [15] \\
\hline POn10 & $\begin{array}{l}\text { December } \\
2002\end{array}$ & $\begin{array}{c}\text { Moribund shrimp hemoculture, } \\
\text { no vibriosis, healthy pond 5, } \\
\text { same healthy farm }\end{array}$ & $\mathrm{N}$ & & [15] \\
\hline POn12 & $\begin{array}{l}\text { December } \\
2002\end{array}$ & $\begin{array}{c}\text { Healthy shrimp hemoculture, } \\
\text { healthy pond } 4 \text {, same healthy } \\
\text { farm }\end{array}$ & $\mathrm{N}$ & $x$ & [15] \\
\hline POn13 & $\begin{array}{l}\text { December } \\
2002\end{array}$ & $\begin{array}{c}\text { Healthy shrimp hemoculture, } \\
\text { same healthy pond } 4 \text {, same } \\
\text { healthy farm }\end{array}$ & $\mathrm{N}$ & $x$ & [15] \\
\hline POn19 & $\begin{array}{l}\text { January } \\
2003\end{array}$ & $\begin{array}{l}\text { Healthy shrimp hemoculture, } \\
\text { same healthy pond } 4 \text {, same } \\
\text { healthy farm }\end{array}$ & V & $X$ & [15] \\
\hline AMn3 & March 2003 & $\begin{array}{c}\text { Moribund shrimp hemoculture, } \\
\text { opportunistic vibriosis }\end{array}$ & V & $x$ & [15] \\
\hline AMn4 & March 2003 & $\begin{array}{c}\text { Moribund shrimp hemoculture, } \\
\text { opportunistic vibriosis, same } \\
\text { episode }\end{array}$ & V & & [15] \\
\hline SOn1 & July 2001 & $\begin{array}{c}\text { Moribund shrimp hemoculture, } \\
\text { no vibriosis }\end{array}$ & $\mathrm{N}$ & & [15] \\
\hline SOn2 & March 2003 & $\begin{array}{l}\text { Healthy shrimp hemoculture, } \\
\text { healthy pond, healthy farm }\end{array}$ & $\mathrm{N}$ & & [15] \\
\hline FTn1 & $\begin{array}{c}\text { January } \\
2001\end{array}$ & $\begin{array}{c}\text { Moribund shrimp hemoculture, } \\
\text { no vibriosis }\end{array}$ & $\mathrm{N}$ & & [15] \\
\hline FTn2 & March 2003 & $\begin{array}{l}\text { Healthy shrimp hemoculture, } \\
\text { healthy pond, healthy farm }\end{array}$ & $\mathrm{V}$ & & [15] \\
\hline SBn2 & March 2003 & $\begin{array}{l}\text { Healthy shrimp hemoculture, } \\
\text { healthy pond, healthy farm }\end{array}$ & $N$ & & [15] \\
\hline Wn1 & $\begin{array}{c}\text { January } \\
2001\end{array}$ & $\begin{array}{c}\text { Moribund shrimp hemoculture, } \\
\text { opportunistic vibriosis }\end{array}$ & V & $x$ & [15] \\
\hline Wn3 & $\begin{array}{l}\text { January } \\
2001\end{array}$ & $\begin{array}{c}\text { Moribund shrimp hemoculture, } \\
\text { opportunistic vibriosis }\end{array}$ & V & $x$ & [15] \\
\hline Wn13 & \multirow{2}{*}{$\begin{array}{l}\text { November } \\
2002\end{array}$} & \multirow{2}{*}{$\begin{array}{c}\text { Moribund shrimp hemoculture, } \\
\text { opportunistic vibriosis (same } \\
\text { animal) }\end{array}$} & $\mathrm{V}$ & $x$ & [15] \\
\hline Wn14 & & & $\mathrm{V}$ & & [15] \\
\hline$B D n 1$ & $\begin{array}{c}\text { February } \\
2003\end{array}$ & $\begin{array}{l}\text { Healthy shrimp hemoculture, } \\
\text { healthy pond, healthy farm }\end{array}$ & $\mathrm{V}$ & & [15] \\
\hline BDn2 & $\begin{array}{c}\text { February } \\
2003\end{array}$ & $\begin{array}{l}\text { Healthy shrimp hemoculture, } \\
\text { healthy pond, healthy farm }\end{array}$ & $\mathrm{V}$ & & [15] \\
\hline$F n 1$ & $\begin{array}{c}\text { February } \\
2003\end{array}$ & $\begin{array}{l}\text { Healthy shrimp hemoculture, } \\
\text { healthy pond, healthy farm }\end{array}$ & $\mathrm{V}$ & & [15] \\
\hline Fn2 & $\begin{array}{c}\text { February } \\
2003\end{array}$ & $\begin{array}{l}\text { Healthy shrimp hemoculture, } \\
\text { healthy pond, healthy farm }\end{array}$ & $\mathrm{N}$ & $x$ & [15] \\
\hline$A Q n 1$ & March 2003 & $\begin{array}{l}\text { Healthy shrimp hemoculture, } \\
\text { healthy pond, healthy farm }\end{array}$ & V & $x$ & [15] \\
\hline AQn2 & March 2003 & $\begin{array}{l}\text { Healthy shrimp hemoculture, } \\
\text { healthy pond, healthy farm }\end{array}$ & V & & [15] \\
\hline MT1 & $\begin{array}{l}\text { January } \\
2000\end{array}$ & $\begin{array}{c}\text { Moribund shrimp hemoculture, } \\
\text { opportunistic vibriosis, } \\
\text { broodstock }\end{array}$ & V & & [15] \\
\hline BLFn1 & March 2001 & $\begin{array}{c}\text { Moribund shrimp hemoculture, } \\
\text { opportunistic vibriosis }\end{array}$ & V & $x$ & [15] \\
\hline BLFn2 & December & Moribund shrimp hemoculture, & V & & [15] \\
\hline
\end{tabular}




\begin{tabular}{|c|c|c|c|c|}
\hline & 2001 & opportunistic vibriosis & & \\
\hline ENn1 & June 2000 & $\begin{array}{l}\text { Healthy shrimp hemoculture, } \\
\text { healthy broodstock }\end{array}$ & $\mathrm{N}$ & [15] \\
\hline ENn2 & June 2000 & $\begin{array}{l}\text { Healthy shrimp hemoculture, } \\
\text { healthy broodstock }\end{array}$ & V & [15] \\
\hline SVn2 & April 2002 & $\begin{array}{c}\text { Moribund shrimp hemoculture, } \\
\text { no vibriosis }\end{array}$ & $\mathrm{N}$ & [15] \\
\hline SVn3 & $\begin{array}{l}\text { February } \\
2003\end{array}$ & $\begin{array}{l}\text { Healthy shrimp hemoculture, } \\
\text { healthy farm }\end{array}$ & $\mathrm{N}$ & [15] \\
\hline ESn2 & June 2000 & $\begin{array}{l}\text { Healthy shrimp hemoculture, } \\
\text { healthy broodstock }\end{array}$ & $\mathrm{N}$ & [15] \\
\hline $\begin{array}{l}\text { V. penaeicida } \\
\text { AM } 101\end{array}$ & May 1995 & $\begin{array}{c}\text { Moribund shrimp hemoculture, } \\
\text { Syndrome } 93\end{array}$ & V & [15] \\
\hline
\end{tabular}


Table 2: Nucleotidic sequences of the primers.

For MLST, the sequence of the primers used in sequencing reaction is indicated in italic.

The amplified gene and the annealing temperature are also indicated for each pair of primers.

\begin{tabular}{|c|c|c|}
\hline gene & Primers sequence & Annealing $\mathrm{T}^{\circ} \mathrm{C}$ \\
\hline rrs & $\begin{array}{l}\text { Forward 5'-CAGGAAACAGCTATGACCAGAGTTTGATCATGGCTCAGA-3' } \\
\text { Reverse 5'-GTAAAACGACGGCCAGGTTACCTTGTTACGACTT-3' }\end{array}$ & 50 \\
\hline gyrB & $\begin{array}{l}\text { F 5'-GAAGTCATCATGACCGTTCTGCAYGCNGGNGGNAARTTYRA-3' } \\
\text { R 5'-AGCAGGGTACGGATGTGCGAGCCRTCNACRTCNGCRTCNGYCAT-3' }\end{array}$ & 58 \\
\hline rpoD & $\begin{array}{l}\text { F 5'-ACGACTGACCCGGTACGCATGTAYATGMGNGARATGGGNACNGT-3' } \\
\text { R 5'-ATAGAAATAACCAGACGTAAGTTNGCYTCNACCATYTCYTTYTT-3' }\end{array}$ & 57 \\
\hline$r c t B$ & $\begin{array}{l}\text { F 5'-CAGGAAACAGCTATGACCATHGARTTYACNGAYTTYCARYTNCAY- 3'’ } \\
\text { R 5'-GTAAAACGACGGCCAYTTNCTYTGHATNGGYTCRAAYTCNCCRT -3' }\end{array}$ & 57 \\
\hline toxR & $\begin{array}{l}\text { F 5'-CAGGAAACAGCTATGACCGANCARGGNTTYGARGTNGAYGAYTC-3' } \\
\text { R 5'-GTAAAACGACGGCCA GTTDKKTTGNCCNCYNGTVGCDATNAC3' }\end{array}$ & 57 \\
\hline \multirow[t]{3}{*}{ recA } & $\begin{array}{l}\text { F 5'-TGGACGAGAATAAACAGAAGGC-3' } \\
\text { R 5'-CCGTTATGCTGTACCAAGCGCCC-3' }\end{array}$ & 55 \\
\hline & AP-PCR RSP 5'-GGAAACAGCTATGACCATGA-3' & \\
\hline & AP-PCR SP 5’-TTGTAAAACGACGGCCAG-3' & \\
\hline
\end{tabular}




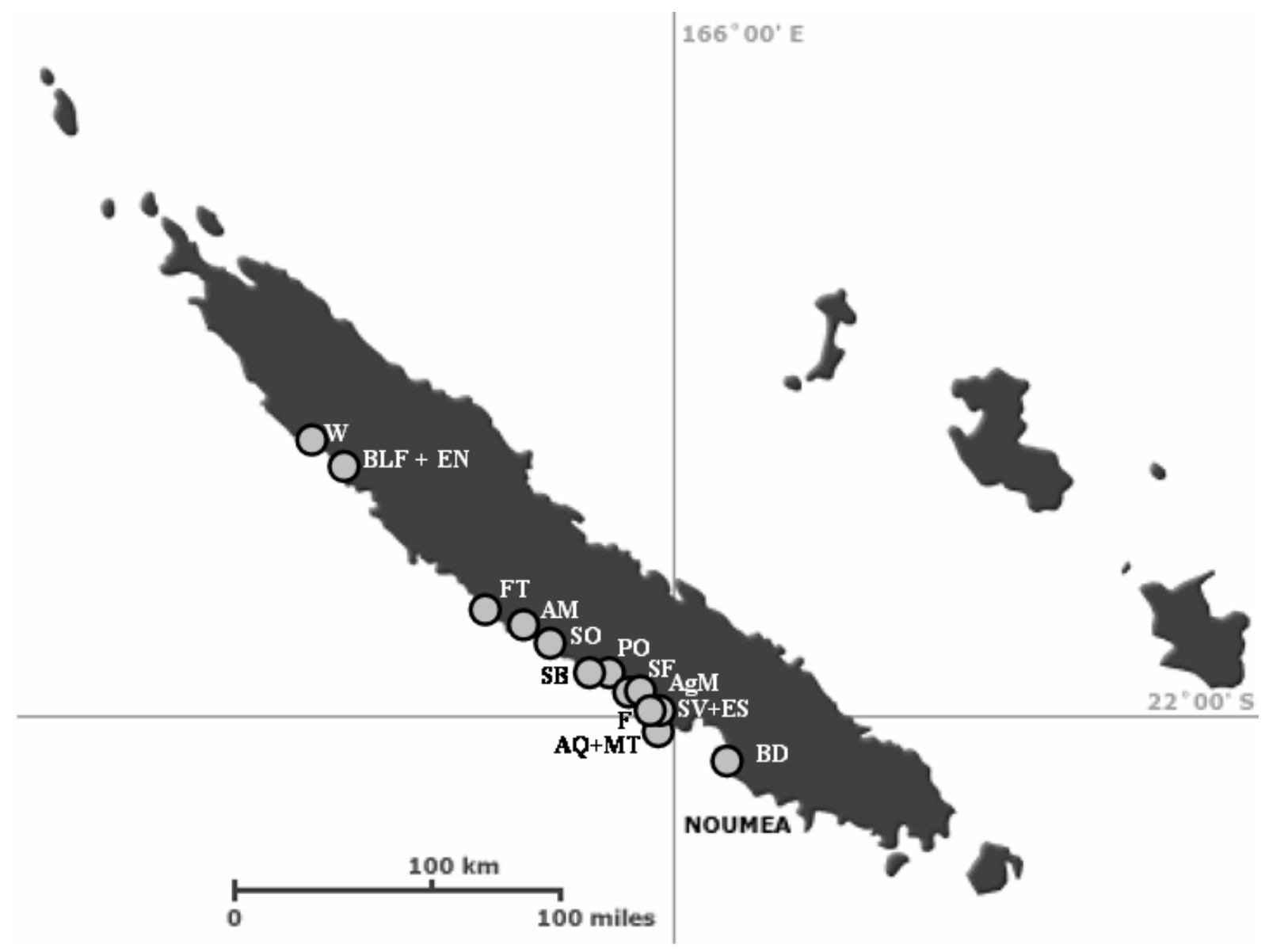

Figure 1: Map of New Caledonian shrimp farms and hatcheries mentioned in this study. Initials ES, EN and MT refer to hatcheries, whereas all the others refer to grow out farms. 


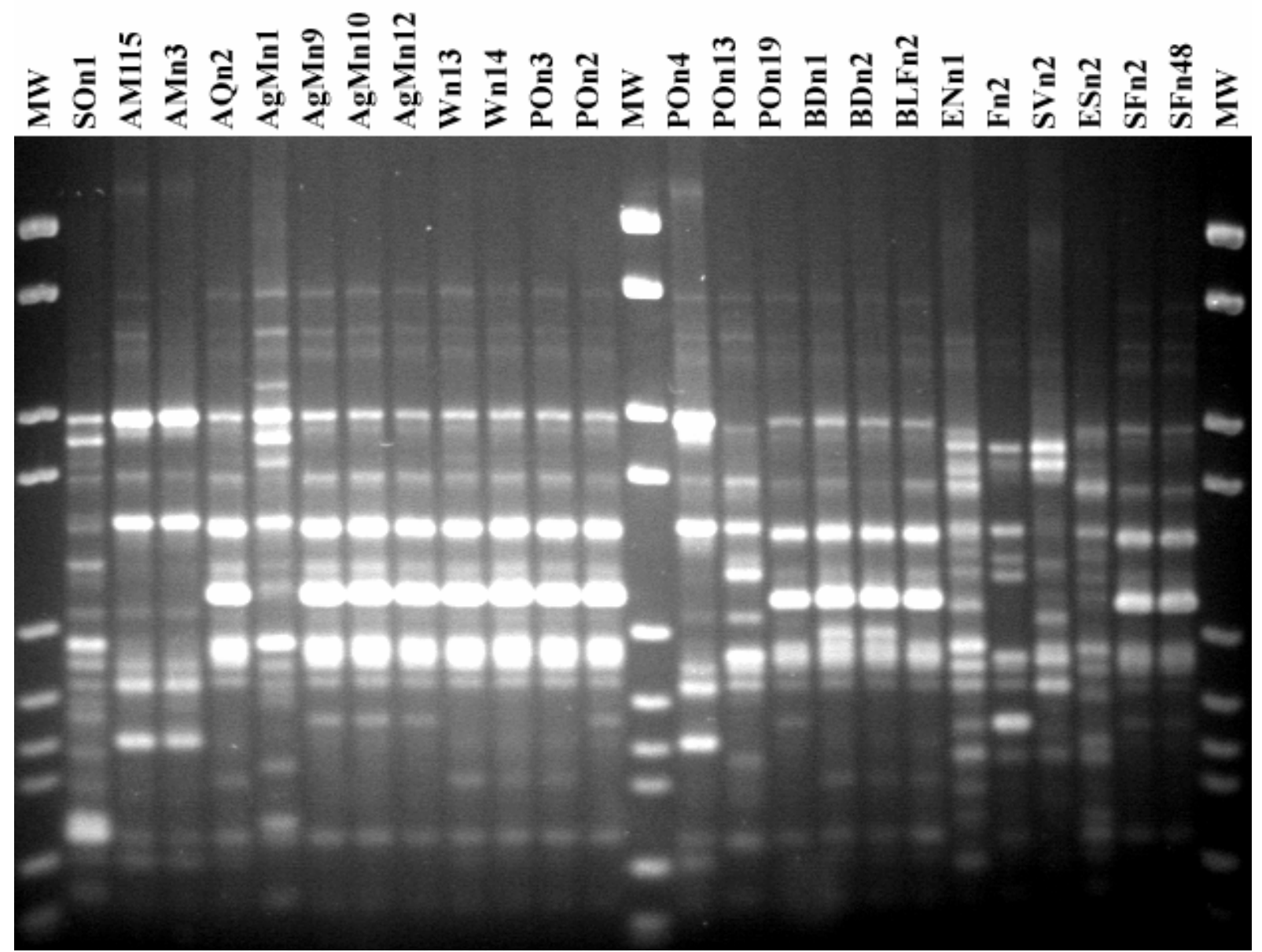

Figure 2: AP-PCR fingerprints obtained with primer SP from a few Vibrio nigripulchritudo wild type isolates. 


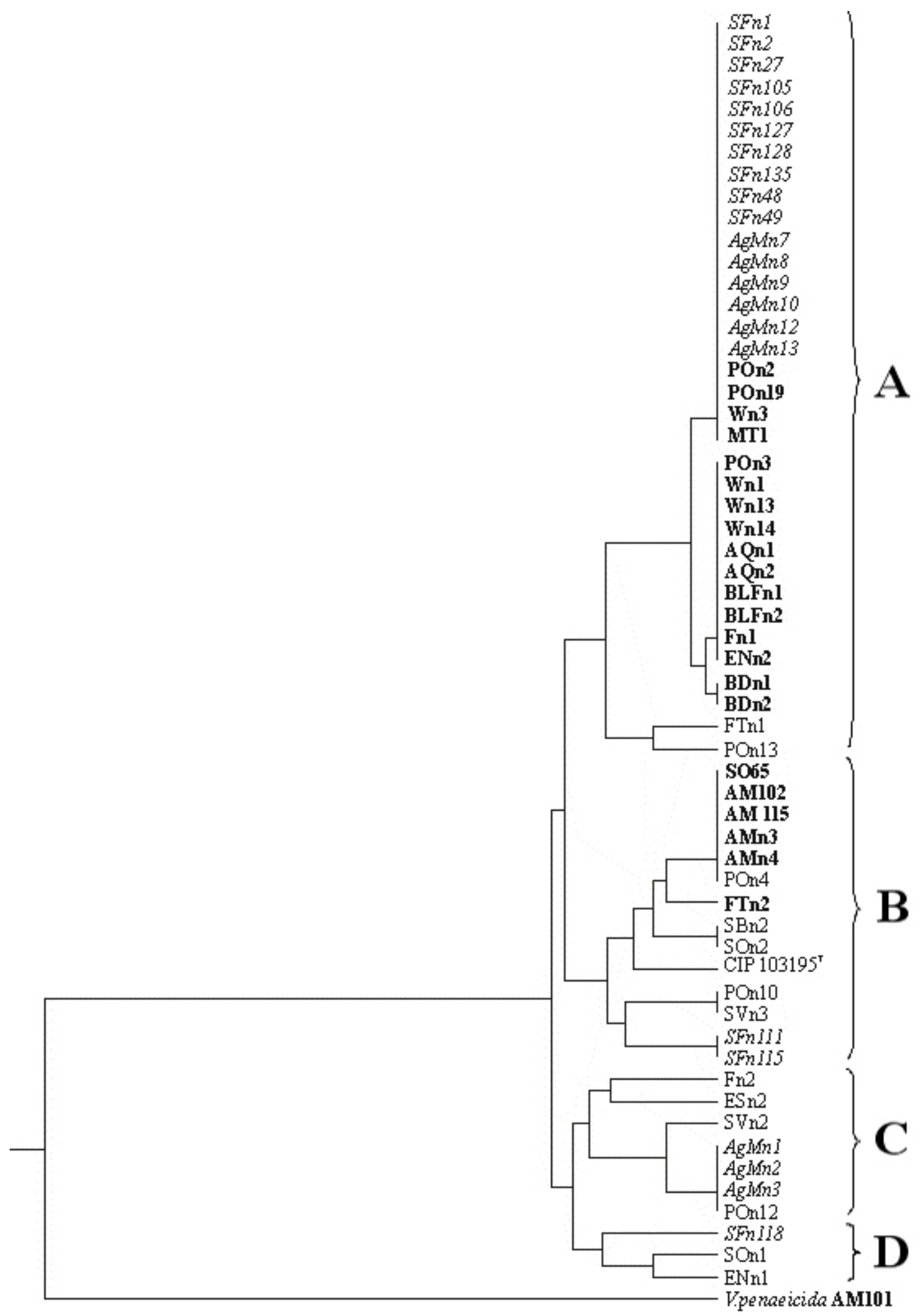

Figure 3: Dendrogram drawn from the presence / absence of major amplicons in each individual AP-PCR fingerprints obtained with primer RSP and SP.

Bold: Virulent isolates (as determined experimentally, see text).

Italics: Isolates collected from farms which are affected by the Summer Syndrome.

Cluster names as mentioned in the text. 


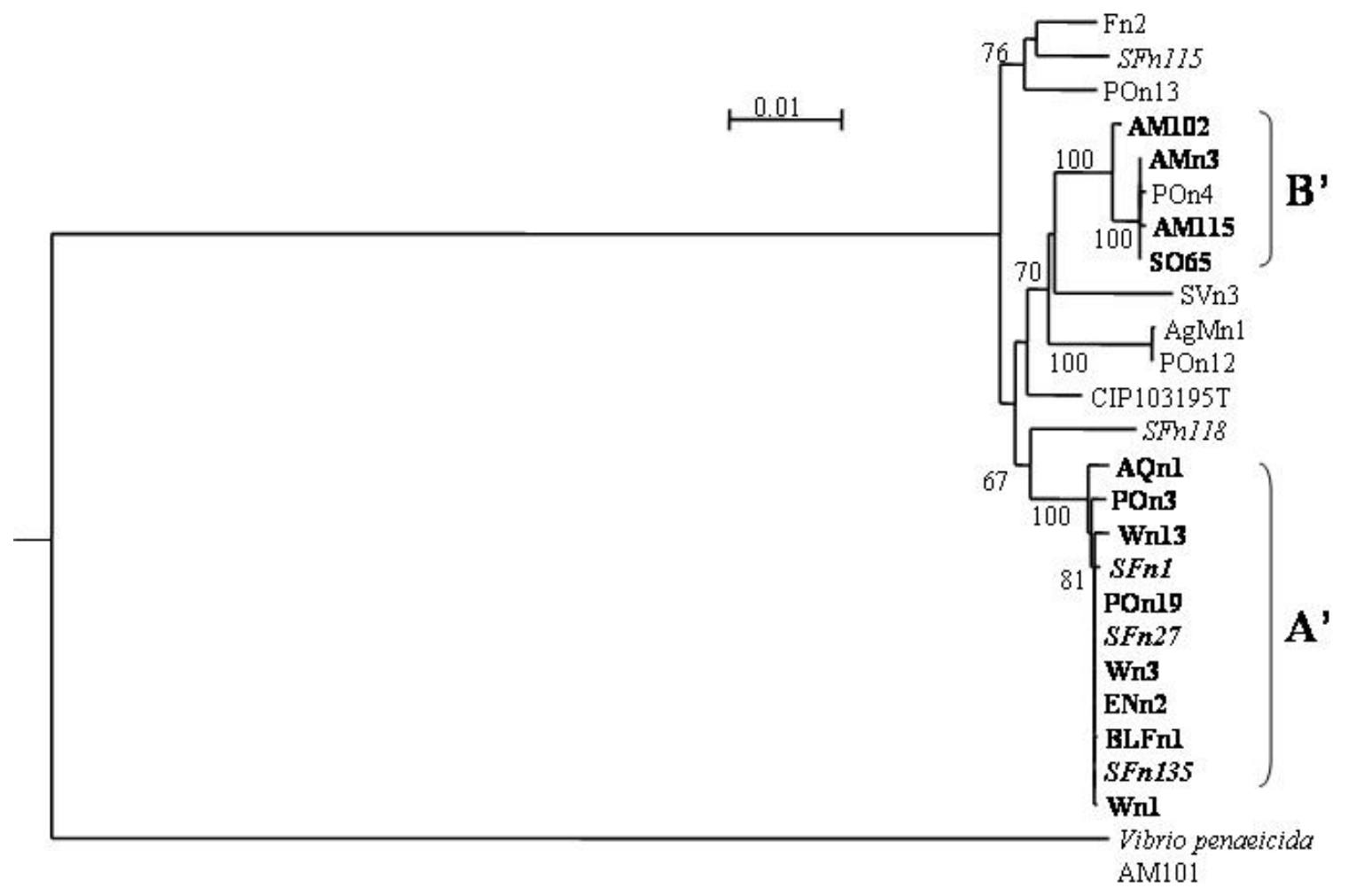

Figure 4: Dendrogram constructed from the alignment of 3430 bp sequences of the six genes recA, rpoD, tox $R, 16 \mathrm{~S}$ rDNA, gyrB and $r c t B$ over a sub-selection of the strains.

Cluster names as mentioned in the text. 